University of Nebraska - Lincoln

DigitalCommons@University of Nebraska - Lincoln

Faculty Publications: Department of Entomology

Entomology, Department of

$10-1-1998$

\title{
Beneficial Arthropods Associated with Buffalograss
}

Tiffany Heng-Moss

University of Nebraska-Lincoln, thengmoss2@unl.edu

Frederick P. Baxendale

University of Nebraska-Lincoln, fbaxendale1@unl.edu

Terrance P. Riordan

University of Nebraska-Lincoln, triordan1@unl.edu

Follow this and additional works at: https://digitalcommons.unl.edu/entomologyfacpub

Part of the Entomology Commons

Heng-Moss, Tiffany; Baxendale, Frederick P.; and Riordan, Terrance P., "Beneficial Arthropods Associated with Buffalograss" (1998). Faculty Publications: Department of Entomology. 137.

https://digitalcommons.unl.edu/entomologyfacpub/137

This Article is brought to you for free and open access by the Entomology, Department of at DigitalCommons@University of Nebraska - Lincoln. It has been accepted for inclusion in Faculty Publications: Department of Entomology by an authorized administrator of DigitalCommons@University of Nebraska - Lincoln. 


\title{
Beneficial Arthropods Associated with Buffalograss
}

\author{
TIFFANY HENG-MOSS ${ }^{1}$ FREDERICK BAXENDALE ${ }^{1}$ AND TERRANCE RIORDAN ${ }^{2}$
}

\begin{abstract}
J. Econ. Entomol. 91(5): 1167-1172 (1998)
ABSTRACT Beneficial arthropods collected from buffalograss, Buchloë dactyloides (Nuttall) Engelmann, evaluation plots and vegetatively established buffalograss lawns included predatory ants, spiders, ground beetles, rove beetles, big-eyed bugs, and several species of hymenopterous parasitoids. Ants and spiders were the most abundant beneficial arthropods collected, representing $84 \%$ of the total beneficial arthropods captured. Pitfall traps collected $>2.5$ times as many $(16,094)$ beneficial arthropods as sod plug samples $(6,054)$, demonstrating that pitfall traps are a more effective technique than sod plugs for capturing highly mobile surface-dwelling arthropods. Families of parasitoids captured on sticky traps during the 2-yr sampling period included Scelionidae, Encyrtidae, Mymaridae, and Trichogrammatidae. Mymarids and trichogrammatids were the most abundant parasitoid families, representing $76.8 \%$ of the total parasitoids collected. Total numbers of beneficial arthropods collected from sites maintained at higher and lower management levels were not significantly different, suggesting that beneficial arthropod abundance may not be adversely affected by the 2 management regimes applied in this study.
\end{abstract}

KEY WORDS buffalograss, beneficial arthropods, natural enemies, integrated pest management (IPM)

Buffalograss, Buchlö̈ dactyloides (NuTtalu) Engelmann, is a perennial, warm-season turfgrass species that requires less mowing, watering, and fewer fertilizer applications than traditional turfgrasses (Riordan et al. 1993). Relatively few insects are known to inhabit and feed on buffalograss. Arthropods previously reported as pests include white grubs, Phyllophaga crinita (Burmesiter); grasshoppers; leafhoppers; mound-building prairie ants; buffalograss webworm, Suratha indentella (Kearfott); the Rhodesgrass mealybug, Antonina graminis (Maskell); an eriophyid mite, Eriophyte slykhuisi (Hall); an undescribed brachypterous chinch bug (Blissus sp.); and the 2 grass-feeding mealybugs, Tridiscus sporoboli (Cockerell) and Trionymus sp. (Baxendale et al. 1994).

Turfgrasses are inhabited by a variety of predators and parasitoids (hereafter collectively referred to as beneficial arthropods) that may help regulate pest populations (Reinert 1978, Cockfield and Potter 1984, Braman and Pendley 1993). Preliminary studies conducted by Baxendale (1990) identified the following beneficial arthropods in buffalograss: big-eyed bugs (Lygaeidae), ladybird beetles (Coccinellidae), syrphid flies (Syrphidae), and numerous parasitoid wasps (Hymenoptera).

In recent years, improved low-maintenance buffalograss cultivars have been developed. Biological control offers a sustainable and environmentally compatible approach for managing insect pests affecting

\footnotetext{
${ }^{1}$ Entomology Department, 202 Plant Industry, University of $\mathrm{Ne}$ braska, Lincoln, NE 68583-0816.

${ }^{2}$ Horticulture Department, 377 Plant Science, University of Nebraska, Lincoln, NE 68583-0724.
}

buffalograss. The development and implementation of an effective biological control program, however, requires detailed information on the abundance, biology, and life history of the beneficial arthropod community. Unfortunately, little information is available on the beneficial arthropods associated with buffalograss. Therefore, the objective of this study was to identify the beneficial arthropod complex in buffalograss, monitor the seasonal activity of selected natural enemies, and investigate the influence of different buffalograss management levels on these beneficial arthropods.

\section{Materials and Methods}

1995 Survey of Beneficial Arthropods. A survey of the beneficial arthropod community in buffalograss was undertaken by collecting and identifying arthropods from buffalograss plots at the John Seaton Anderson Turfgrass and Ornamental Research Facility (JSA Facility), located at the University of Nebraska Agricultural Research and Development Center (ARDC), near Mead, NE, and from vegetatively established turfs on the University of Nebraska East Campus (UN-L Campus), Lincoln, NE. Samples were collected every $14 \mathrm{~d}$ to obtain information on natural enemy composition and seasonal activity. Each sampling period, 18 pitfall and 18 sod plug samples were collected from 6 evaluation plots, each $63.2 \mathrm{~m}^{2}$, at the JSA Facility, and from 3 vegetatively established areas, each $74.3 \mathrm{~m}^{2}$, at the UN-L Campus. The JSA Facility sites (soil, silty clay loam; $\mathrm{pH}, 6.8-7.2$; thatch, $0.64 \mathrm{~cm}$ ) were mowed every $14 \mathrm{~d}$ at $6.25 \mathrm{~cm}$ (clippings returned), received 2 applications of $2.4 \mathrm{~g} \mathrm{~N} \mathrm{~m}^{-2}(20$ 
10-20), and were irrigated as needed to maintain optimal growing conditions. The UN-L Campus sites (soil, silty clay loam; $\mathrm{pH}, 6.9-7.3$; thatch, $0.64 \mathrm{~cm}$ ) were mowed every $14 \mathrm{~d}$ at $6.25 \mathrm{~cm}$ (clippings returned), received 2 applications of $3.7 \mathrm{~g} \mathrm{~N} \mathrm{~m}^{-2}(38-0-0)$, and were irrigated as needed. The JSA Facility sites were surrounded by turf, native grasses, and agricultural crops, whereas the UN-L Campus sites were bordered by highly maintained turf and landscape ormamentals. Sampling began the lst wk in May and continued through the last week of October.

Arthropods were collected using plastic pitfall traps (10 cm diameter) containing ethylene-glycol killing solution (Morrill 1975), and sod plugs cut with a $10.6-\mathrm{cm}$ golf cup cutter to a depth of $7.5 \mathrm{~cm}$. Pitfall traps were placed $2.4 \mathrm{~m}$ apart in the center of each plot and operated continuously through each 14-d sample interval. Sod plug samples were taken near each pitfall trap. Plugs were placed in Berlese funnels for $48 \mathrm{~h}$ to extract beneficial arthropods. Ultimately, arthropods were stored in $70 \%$ ethyl alcohol for later analyses. Arthropods collected in samples were identified and grouped into orders and families known to contain insect predators or parasitoids.

1996 Survey of Beneficial Arthropods/Management Practices. Samples were again collected in 1996 from the previously described locations to identify additional beneficial arthropods, collect seasonal activity information, and determine the influence of management practices on the composition and seasonal activity of natural enemies. Beneficial arthropods were sampled from the 1st wk in May to the last week of October. Every 14 d, 18 pitfall and 18 sod plug samples were collected from 3 high maintenance sites and 3 low maintenance sites at both the JSA Facility ( 46.5 $\mathrm{m}^{2}$ ) and the UN-L Campus $\left(55.7 \mathrm{~m}^{2}\right)$. Soil type, $\mathrm{pH}$, thatch history, surrounding vegetation, and pitfall trap and sod plug sample arrangement were the same as described in the previous section. The high maintenance sites were mowed every $14 \mathrm{~d}$ at $6.25 \mathrm{~cm}$ (clippings returned), received 3 applications of $3.7 \mathrm{~g} \mathrm{~N} \mathrm{~m}^{-2}$ (20-10-20), and were irrigated as needed to maintain optimal growing conditions. Low maintenance sites were mowed once in the spring and fall (clippings returned), received no nitrogen applications, and were not irrigated. In accordance with recommended buffalograss maintenance practices (Riordan et al. 1996), insecticides were not incorporated into either management program.

Additional samples were collected from a buffalograss seed production facility (soil, silty clay loam; $\mathrm{pH}, 6.5$; thatch, $0.32 \mathrm{~cm}$ ) near Murdock, NE. This location provided an opportunity to identify additional beneficial arthropods from buffalograss maintained under a totally different management regime. Samples were collected from a 'Texoka' seed production field $\left(3,716.0 \mathrm{~m}^{2}\right)$ that remained unmowed until harvest in early August, received a total of $36.3 \mathrm{~kg} \mathrm{~N}$ year $^{-1}$ (34-0-0), applications of the insecticide carbaryl, and herbicide applications of atrazine and 2, 4-dichlorophenoxyacetic acid (2, 4-d). Every 14 d, 80 sod plug samples (each $10.6 \mathrm{~cm}$ ) were taken every $3 \mathrm{~m}$ along a series of transects. Plugs were placed in Berlese funnels for $48 \mathrm{~h}$ to extract beneficial arthropods. The vegetation surrounding this site included buffalograss, agronomic crops, and wildflowers grown for seed.

Survey of Parasitoids: 1995 and 1996. Yellow adhesive sticky traps ( 15 by $30 \mathrm{~cm}$ ) were used to monitor the seasonal abundance of selected parasitoid families associated with buffalograss (Bridges and Pass 1969, Dowell and Cherry 1981, Neuenschwander 1982, Heng-Moss et al. 1997). Traps were constructed by stapling rolled sticky strip cylinders to $30 \mathrm{~cm}$ wooden stakes. Ten yellow sticky traps were randomly placed in a buffalograss evaluation plot at the JSA Facility where large numbers of mealybugs ( mean $=54.3$ mealybugs per $230 \mathrm{~cm}^{2}$ ) had been collected in 1994 . This evaluation plot $\left(25.4 \mathrm{~m}^{2}\right)$ was mowed every $14 \mathrm{~d}$ at $6.25 \mathrm{~cm}$ (clippings returned), received 2 applications of $2.4 \mathrm{~g} \mathrm{~N} \mathrm{~m}^{-2}(20-10-20)$, and was irrigated as needed to maintain optimal growing conditions. The plot was surrounded by cool- and warm-season grasses and agronomic crops. Every $14 \mathrm{~d}$, traps were collected and replaced with new traps. Monitoring began during the 3rd wk in May and continued through the last week in October for both the 1995 and 1996 seasons. Parasitoids were removed from the sticky traps using Histo-Clear II (Histological Clearing Agent, National Diagnostics, Atlanta, GA) and were identified based on the taxonomic keys of Goulet and Huber (1993). Because identifying and monitoring all parasitoids captured on sticky traps proved prohibitively laborintensive, only potential mealybug and chinch bug parasitoids captured in relatively large numbers during the first 2 sampling periods were recorded during the remainder of the season.

Statistical Analyses. All analyses were performed on both the observed counts and the logarithm of the count plus 1 . The log transformation was used to stabilize the variance. However, because the conclusions were the same for both analyses, results are presented for the raw data to simplify interpretation. Mixed model analysis (PROC MIXED, SAS Institute 1997) was conducted for each beneficial arthropod group and parasitoid family to detect differences in seasonal abundance between years and locations (Littell et al. 1996). Differences between beneficial arthropod means on high and low maintenance sites were tested using $t$-tests (PROC $t$-test, SAS Institute 1990).

\section{Results and Discussion}

Survey of Beneficial Arthropods: 1995 and 1996. Numerous beneficial arthropods were collected on buffalograss, including big-eyed bugs (Geocoris spp.), ground beetles (Carabidae), rove beetles (Staphylindae), predatory ants (Formicidae), spiders (Araneae), and several species of parasitoid wasps (Table 1). Ants and spiders were the most abundant natural enemies collected with both pitfall and sod plug sampling techniques and represented $84 \%$ of the total beneficial arthropods collected. Ground beetles, rove beetles, big-eyed bugs, and parasitoid wasps comprised the remaining $16 \%$ of the total natural enemies 
Table 1. Total number of beneficial arthropods collected from buffalograss stands at 2 locations in Nebraska during 1995 and 1996

\begin{tabular}{|c|c|c|c|c|c|c|c|c|c|c|}
\hline \multirow{3}{*}{$\begin{array}{l}\text { Beneficial } \\
\text { arthropods }\end{array}$} & \multicolumn{4}{|c|}{1995} & \multicolumn{4}{|c|}{1996} & \multirow{3}{*}{$\%$ total } & \multirow{3}{*}{$\begin{array}{c}1996 \\
\text { Murdock } \\
\text { Plug }\end{array}$} \\
\hline & \multicolumn{2}{|c|}{$\mathrm{JSA}^{a}$} & \multicolumn{2}{|c|}{$\mathbf{U N}-\mathbf{L}^{b}$} & \multicolumn{2}{|c|}{ JSA } & \multicolumn{2}{|c|}{ UN-L } & & \\
\hline & $\mathrm{Pit}^{c}$ & Plug $^{d}$ & Pit & Plug & Pit & Plug & Pit & Plug & & \\
\hline Ants & 1,345 & 927 & 1,728 & 909 & 2,373 & 1,140 & 2,836 & 2,086 & 60.2 & 9,890 \\
\hline Spiders & 2,053 & 268 & 500 & 96 & 1,316 & 181 & 774 & 73 & 23.8 & 294 \\
\hline Ground beetles & 460 & 20 & 62 & 5 & 526 & 23 & 189 & 23 & 5.9 & 12 \\
\hline Rove beetles & 282 & 38 & 156 & 51 & 91 & 33 & 182 & 97 & 4.2 & 19 \\
\hline Big-eyed bugs & 150 & 12 & 15 & 2 & 148 & 16 & 42 & 4 & 1.8 & 36 \\
\hline Parasitoids & 297 & 7 & 366 & 10 & 118 & 20 & 85 & 13 & 4.1 & 73 \\
\hline
\end{tabular}

${ }^{a}$ Buffalograss evaluation plots at the John Seaton Anderson Turf and Ornamental Research Facility near Mead, NE.

${ }^{b}$ Vegetative buffalograss areas at the University of Nebraska East Campus, Lincoln, NE.

${ }^{c}$ Pitfall traps contained ethylene-glycol killing solution.

${ }^{d}$ Sod plugs were cut with a $10.6-\mathrm{cm}$ golf cup cutter.

captured. Pitfall traps collected the largest number of beneficial arthropods (Table 1), especially when ants were not included in overall totals. This suggests that pitfall traps may be more effective than sod plugs for capturing highly mobile, surface-dwelling arthropods.

Predatory ants were the most abundant natural enemy collected at both the JSA Facility and the UN-L Campus (Table 1). Ant genera collected included Formica, Solenopsis, Monomorium, Myrmica, Ponera, and Iridomyrmex. The greatest number of ants was collected from June to August at both sample locations (Fig. 1). Although ant numbers did not differ dramatically among sampling periods, they were highest during July, August, and September of 1996. Significantly more ants were collected during 1996 than 1995 ( $F=$ $4.88 ; \mathrm{df}=1,17 ; P<0.04)$, but ant numbers were similar for both locations $(F=0.62 ; \mathrm{df}=1,17 ; P<0.44)$.

Spiders also were well represented throughout the sampling period (Table 1). Families collected included Thomisidae, Lycosidae, Araneidae, Clubionidae, Gnaphosidae, and Tetragnathidae. Spider abundance steadily increased from May to August, then decreased throughout the remainder of the season (Fig. 1). There was a significant interaction between year and location $(F=34.94 ; \mathrm{df}=1,17 ; P<0.0001)$. The mean number of spiders at the UN-L Campus did not change significantly from 1995 to 1996 ( $t=0.19$, $\mathrm{df}=17, P<0.85)$. However, the mean number of spiders did change significantly at the JSA Facility during this same period $(t=8.54, \mathrm{df}=17, P<0.0001)$. In both years, the mean number of spiders was significantly greater at the JSA Facility than at the UN-L Campus $(1995, t=11.62, \mathrm{df}=17, P<0.0001 ; 1996, t=$ $3.25, \mathrm{df}=17, P<0.005)$

Ground beetles were collected throughout the 2 sample seasons (Table 1; Fig. 1). Genera of ground beetles included Scarites, Pterostichus, Harpalus, Gabritula, Bradycellus, and Amara. Significantly more ground beetles were collected at the JSA Facility than at the UN-L Campus $(F=36.98 ; \mathrm{df}=1,17 ; P<0.0001)$. Ground beetle counts were not significantly different between 1995 and $1996(F=0.86 ; \mathrm{df}=1,17 ; P<0.37)$.

Only 2 subfamilies of rove beetles (Oxytelinae and Staphylininae) were collected. There was a significant interaction between year and location $(F=5.17$; $\mathrm{df}=$ $1,17 ; P<0.04)$. The mean number of rove beetles collected at the UN-L Campus did not change significantly from 1995-1996 $(t=-0.31, \mathrm{df}=17, P<0.76)$. However, the mean number of rove beetles did change significantly at the JSA Facility during this same time period $(t=3.05, \mathrm{df}=17, P<0.007)$. In 1996, the mean number of rove beetles was significantly greater at the UN-L Campus than at the JSA Facility $(t=-2.28, \mathrm{df}=17, P<0.04)$.

More big-eyed bugs were collected at the JSA Facility than at the UN-L Campus $(F=13.80$; df $=1,17$; $P<0.002$ ) (Table 1). Big-eyed bug counts were not significantly different between years sampled $(F=$ $0.61 ; \mathrm{df}=1,17 ; P<0.45$ ). Although relatively few big-eyed bugs were collected in either year (Fig. 1), past observations suggest that big-eyed bugs may be important mealybug predators in buffalograss (Baxendale et al. 1994).

Hymenopterous parasitoids (Scelionidae, Encyrtidae, Mymaridae, and Trichogrammatidae) were collected from pitfall traps and sod plug samples at both locations in 1995 and 1996 (Table 1; Fig. 1). More parasitoids were collected during 1995 than in 1996 $(F=15.36 ; \mathrm{df}=1,17 ; P<0.001)$ and parasitoid numbers were similar for both locations $(F=0.01 ; \mathrm{df}=$ $1,17 ; P<0.92)$.

Ants were the most abundant predator collected at the buffalograss seed production facility near Murdock, NE (Table 1). With the exception of ants and spiders, however, fewer beneficial arthropods were collected from this location than from the other 2 survey locations. The reduced diversity and abundance of beneficial arthropods at this location may have resulted from the regular applications of carbaryl applied to control chinch bugs (Blissus sp.) and herbicides (atrazine and 2, 4-dichlorophenoxyacetic acid) used for broadleaf weed control.

Cockfield and Potter (1984) and Braman and Pendley (1993) reported similar complexes of natural enemies associated with both cool- and warm-season turfgrasses in other regions in the United States, although both found greater diversity of beneficial arthropod species. Because buffalograss has fewer insect pests (prey species) than most other turfgrasses, it was not unexpected to find fewer natural enemies as well. Additional studies are needed to further characterize 

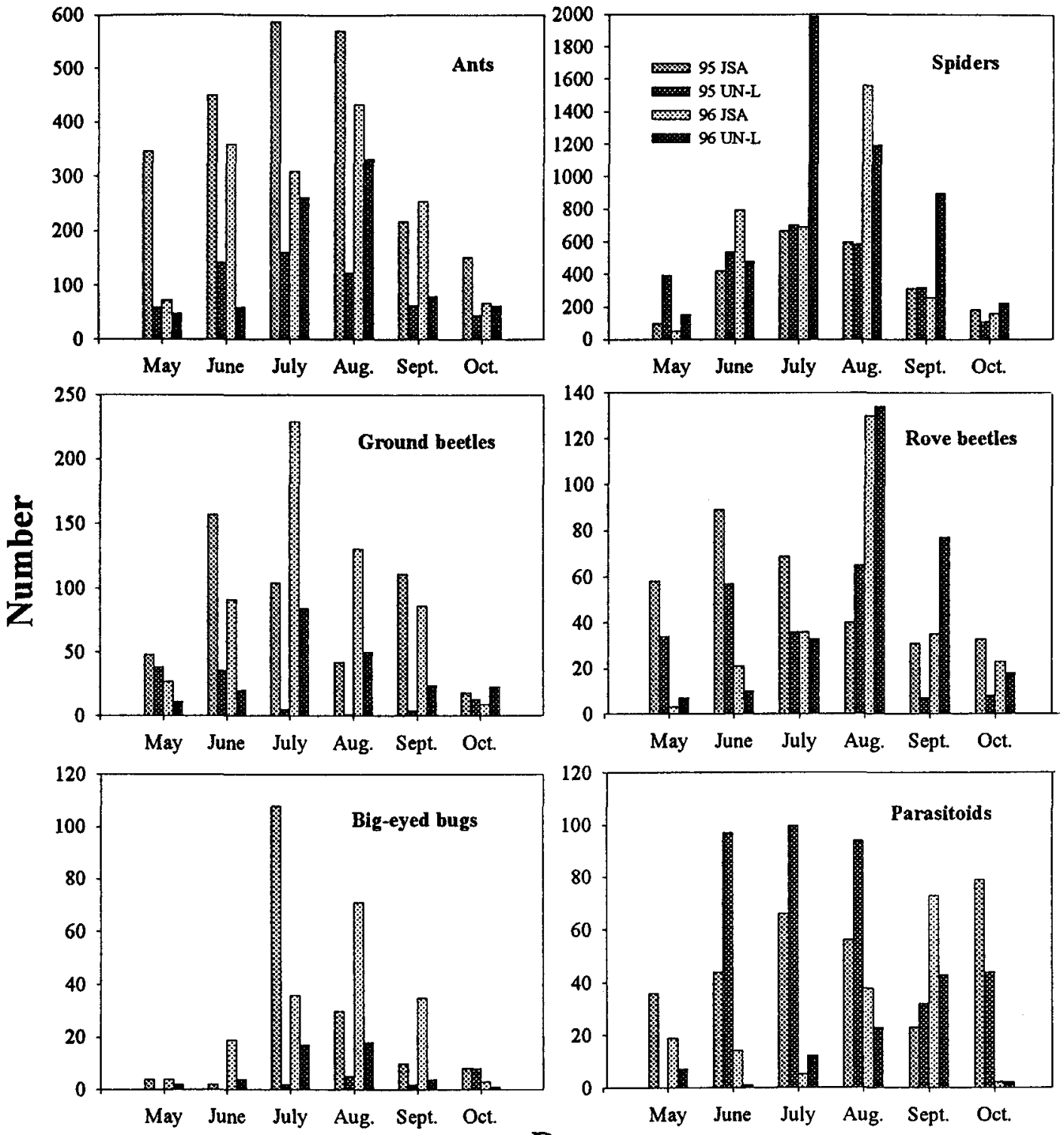

Date

Fig. 1. Beneficial arthropods collected during 1995 and 1996 from pitfall traps and sod plug samples at the JSA Facility and UN-L Campus. Each bar reflects 2 sampling dates.

the biology and ecology of these beneficial arthropods.

Survey of Parasitoids: 1995 and 1996. Numerous parasitoids including Scelionidae, Encyrtidae, Mymaridae, and Trichogrammatidae were captured on sticky traps during the 2-yr study (Table 2). Mymaridae (4 species) was the most abundant family of parasitoids collected, representing $39.7 \%$ of the total ( $\mathrm{Ta}$ ble 2). Most mymarids were collected from July to October (Fig. 2). More mymarids were collected during 1996 than in $1995(F=27.28 ; \mathrm{df}=1,218 ; P<$ 0.0001 ).

Trichogrammatids ( 2 species) also were well represented throughout the sample period (Table 2 ). In contrast to the mymarids, more trichogrammatids were collected in 1995 than in $1996(F=24.47$; df $=$ $1,218 ; P<0.0001)$. Numbers of collected trichogrammatids were highest from July to September (Fig. 2).

Table 2. Total number of hymenopterous parasitoids collected on sticky traps at the JSA Facility during 1995 and 1996

\begin{tabular}{lrrrr}
\hline \hline & 1995 & 1996 & Total & \% total \\
\hline Mymaridae & 1,234 & 2,580 & 3,814 & 39.7 \\
Trichogrammatidae & 2,652 & 918 & 3,570 & 37.1 \\
Encyrtidae & 593 & 1,406 & 1,999 & 20.8 \\
Scelionidae & 98 & 134 & 232 & 2.4 \\
\hline
\end{tabular}




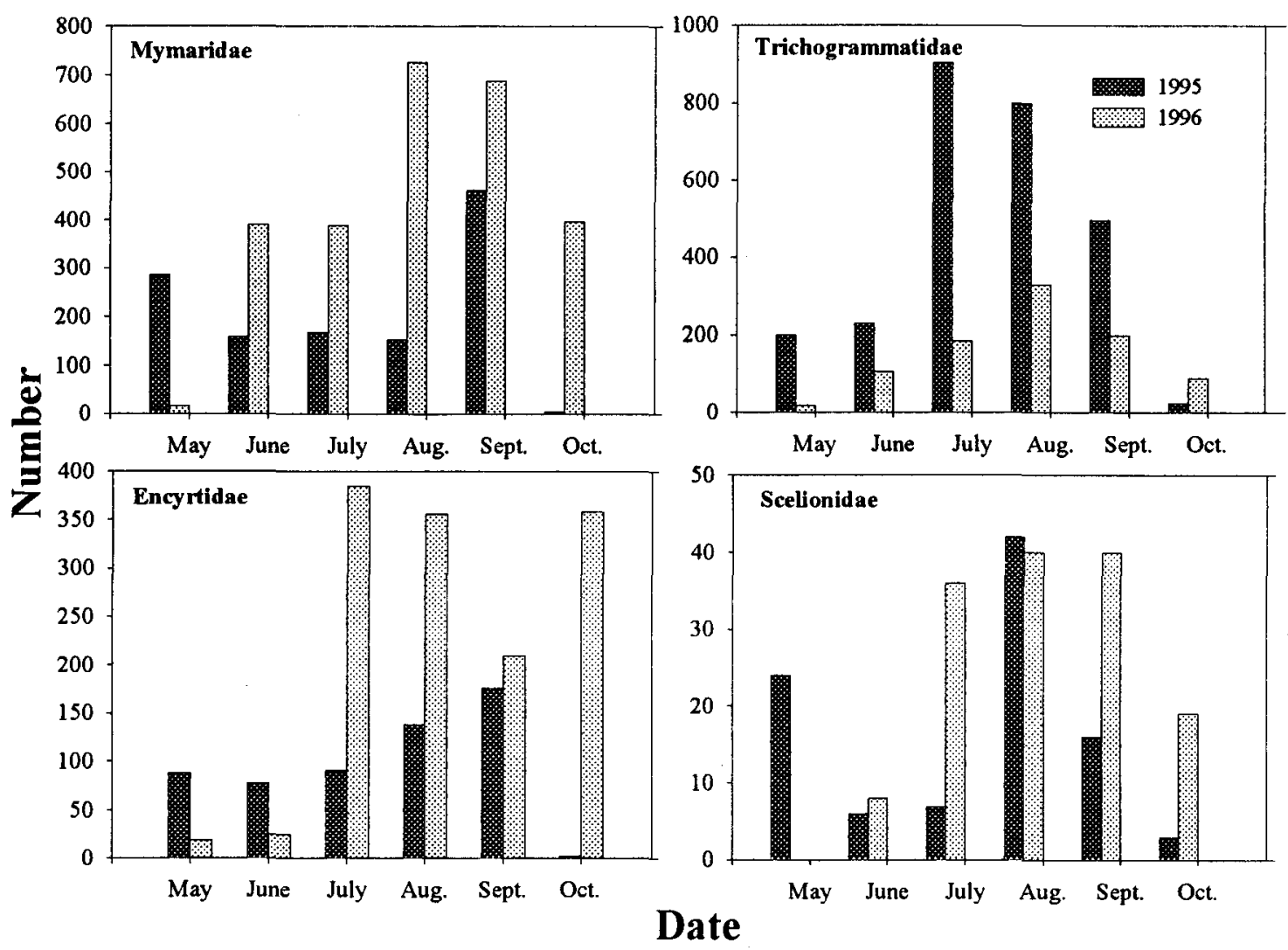

Fig. 2. Parasitoid families collected from sticky traps during 1995 and 1996 at the JSA Facility. Each bar reflects 2 sampling dates.

Table 3. Beneficial arthropods collected from sod plug samples and pitfall traps at 2 locations in Nebraska during 1996

\begin{tabular}{|c|c|c|c|c|c|}
\hline $\begin{array}{l}\text { Beneficial } \\
\text { arthropods }\end{array}$ & $n$ & $\begin{array}{c}\text { Mean } \pm S E \\
\text { high }^{a}\end{array}$ & $\underset{\text { low }^{b}}{\operatorname{Mean}} \pm \mathrm{SE}$ & $t$-statistic & $P$-value ${ }^{c}$ \\
\hline Ants & 234 & $15.19 \pm 1.40$ & $22.53 \pm 3.99$ & -1.74 & 0.08 \\
\hline Spiders & 234 & $5.13 \pm 0.49$ & $5.23 \pm 0.39$ & -0.16 & 0.87 \\
\hline Ground beetles & 234 & $1.75 \pm 0.16$ & $1.71 \pm 0.19$ & 0.17 & 0.87 \\
\hline Rove beetles & 234 & $0.80 \pm 0.10$ & $0.91 \pm 0.19$ & -0.52 & 0.60 \\
\hline Big-eyed bugs & 234 & $0.47 \pm 0.08$ & $0.41 \pm 0.07$ & 0.59 & 0.55 \\
\hline Parasitoids & 234 & $0.54 \pm 0.10$ & $0.53 \pm 0.09$ & 0.03 & 0.97 \\
\hline
\end{tabular}

${ }^{a}$ High-maintenance sites were mowed every $2 \mathrm{wk}$ at $6.25 \mathrm{~cm}$ (clippings returned), received 3 applications of $3.7 \mathrm{~g} \mathrm{~N} \mathrm{~m}^{-2}(20-10-20)$, and were irrigated as needed to maintain optimal growing conditions.

${ }^{b}$ Low maintenance sites were mowed once in the spring and fall (clipping returned), received no nitrogen applications, and were not irrigated.

'Significantly different at $P<0.05$.

Two species of encyrtids also were collected on sticky traps (Table 2), including Rhopus nigroclavatus (Ashmead), a known parasitoid of the buffalograss mealybugs, T. sporoboli and Trionymus sp. (HengMoss 1997). Encyrtid abundance steadily increased throughout both seasons; with counts highest during July, August, and September (Fig. 2). Substantially more encyrtids were collected in 1996 than in 1995 $(F=20.94 ; \mathrm{df}=1,218 ; P<0.0001)$.

Scelionids (1 species) also were present in 1995 and 1996 (Table 2). The greatest numbers were collected from July to September (Fig. 2). Total scelionid counts were similar for both years $(F=2.36 ; \mathrm{df}=1,218 ; P<$ $0.13)$.

Because the seasonal abundance of a parasitoid is normally dependent on the population dynamics of its host, it is difficult to fully explain the fluctuations in parasitoid population levels until the hosts of these parasitoids are known. Further research is needed to characterize parasitoid and host interactions in buffalograss.

1996 Management Practices. Natural enemies collected in sod plugs and pitfall traps from the high and low maintenance sites included predatory ants, spi- 
ders, ground beetles, rove beetles, big-eyed bugs, and parasitoid wasps (Table 3). Total numbers of natural enemies collected from high and low maintenance sites were not significantly different. Several studies (e.g., Cockfield and Potter 1985, Braman and Pendley 1993) have shown that both the abundance and species composition of beneficial arthropods in turfgrasses can be influenced by the type and level of management. Our results, however, suggest that natural enemy composition and abundance in buffalograss is not strongly affected by the level of turfgrass maintenance as defined by this study.

An understanding of the beneficial arthropod community is important for the development of site-specific insect management recommendations for buffalograss. Our research provides essential information on the composition, seasonal abundance, and influence of management practices on natural enemies associated with buffalograss.

\section{Acknowledgments}

We gratefully acknowledge L. Higley and Z B Mayo for reviewing the manuscript, L. Young for statistical advice, and T. Weinhold, R. Roselle and L. Wit for technical assistance. This work was supported in part by University of Nebraska Agricultural Experiment Station Project 17-062, the United States Golf Association, and the Nebraska Turfgrass Foundation. This is paper 12132 of the journal series of the Agricultural Research Division, University of Nebraska-Lincoln.

\section{References Cited}

Baxendale, F. P. 1990. Insects associated with buffalograss. Golf Course Manage. 58: 24-28.

Baxendale, F. P., J. M. Johnson-Cicalese, and T. P. Riordan. 1994. Tridiscus sporoboli and Trionymus sp. (Homoptera: Pseudococcidae): potential new mealybug pests of buffalograss turf. J. Kans. Entomol. Soc. 67: 169-172.

Braman, S. K, and A. F. Pendley. 1993. Relative and seasonal abundance of beneficial arthropods in centipedegrass as influenced by management practices. J. Econ. Entomol. 86: 494-504.

Bridges, E. T., and B. C. Pass. 1969. The effect of color of ambient light on the pea aphid and its parasite Aphidius smithi. Proc. North Central Branch Entomol. Soc. Am. 24: 33.
Cockfield, S. D., and D. A. Potter. 1984. Predatory insects and spiders from suburban lawns in Lexington, Kentucky. Gt. Lakes Entomol. 17: 179-184.

Cockfield, S. D., and D. A. Potter. 1985. Predatory arthropods in high- and low-maintenance turfgrass. Can. Entomol. 117: 423-429.

Dowell, R. V., and R. H. Cherry. 1981. Survey traps for parasitoids, and coccinellid predators of the citrus blackfly, Aleurocanthus woglumi. Entomol. Exp. Appl. 29: 356362.

Goulet, H., and T. J. Huber. 1993. Hymenoptera of the world: an identification guide to families. Canada Communication Group, Ottawa, Canada.

Heng-Moss, T. M., F. P. Baxendale, J. M. Johnson-Cicalese, and T. P. Riordan. 1997. Non-destructive monitoring of mealybugs (Homoptera: Pseudococcidae) on Buchloë dactyloides. Int. Turfgrass Soc. Res. J. 8: 997-1002.

Heng-Moss, T. M. 1997. Beneficial arthropods associated with buffalograss and the influence of Rhopus nigroclavatus (Ashmead) on buffalograss mealybug populations. M.S. thesis, University of Nebraska, Lincoln.

Littell, R. C., G. A. Milliken, W. W. Stroup, and R. D. Wolfinger. 1996. SAS system for mixed models. SAS Institute, Cary, NC.

Morrill, W. L. 1975. Plastic pitfall trap. Environ. Entomol. 4: 596.

Neuenschwander, P. 1982. Beneficial insects caught by yellow traps used in mass trapping of the olive fly, Dacus oleae. Entomol. Exp. Appl. 32: 286-296.

Reinert, J. A. 1978. Natural enemy complex of the southern chinch bug in Florida. Ann. Entomol. Soc. Am. 71: 728731

Riordan, T. P., S. A. de Shazer, J. M. Johnson-Cicalese, and R. C. Shearman. 1993. An overview of breeding and development of buffalograss. Int. Turfgrass Soc. Res. J. 7: 816-822.

Riordan, T. P., F. P. Baxendale, R. E. Gaussoin, and J. E. Watkins. 1996. Buffalograss: an alternative native grass for turf. Nebr. Coop. Ext. G 96-1297-A.

SAS Institute. 1990. User's manual, version 6. SAS Institute, Cary, NC.

SAS Institute. 1997. SAS/STAT Software: changes and enhancements through release 6.12. SAS Institute, Cary, NC.

Received for publication 27 January 1998; accepted 16 June 1998. 